Article

\title{
Physicochemical Effects of Lactobacillus plantarum and Lactobacillus casei Cocultures on Soy-Wheat Flour Dough Fermentation
}

\author{
Bernadette-Emóke Teleky ${ }^{1}\left(\mathbb{D}\right.$, Gheorghe Adrian Martău ${ }^{1,2}$ (D) and Dan Cristian Vodnar ${ }^{1,2, *(1)}$ \\ 1 Institute of Life Sciences, University of Agricultural Sciences and Veterinary Medicine, Calea Mănăștur 3-5, \\ 400372 Cluj-Napoca, Romania; bernadette.teleky@usamvcluj.ro (B.-E.T.); adrian.martau@usamvcluj.ro (G.A.M.) \\ 2 Faculty of Food Science and Technology, University of Agricultural Sciences and Veterinary Medicine, \\ Calea Mănăștur 3-5, 400372 Cluj-Napoca, Romania \\ * Correspondence: dan.vodnar@usamvcluj.ro; Tel.: +40-74-734-1881
}

Received: 24 November 2020; Accepted: 15 December 2020; Published: 18 December 2020

\begin{abstract}
In contemporary food production, an important role is given to the increase in the nutritional quality of foodstuff. In the bakery industry, one of the main cereals used is wheat flour (WF), which creates bread with proper sensory evaluation but is nutritionally poor. Soy-flour (SF) has increased nutrient content, and its consumption is recommended due to several health benefits. Dough fermentation with lactic acid bacteria (LAB) increases bread shelf life, improves flavor, and its nutritional quality, mostly due to its high organic acid production capability. In the present study, the addition of SF to WF, through fermentation with the cocultures of Lactobacillus plantarum and Lactobacillus casei was analyzed. Three different batches were performed by using WF supplemented with SF, as follows: batch A consisting of $90 \% \mathrm{WF}$ and 10\% SF; batch B-95\% WF and 5\% SF; batch C-100\% WF. The fermentation with these two LABs presented several positive effects, which, together with increased SF content, improved the dough's rheological and physicochemical characteristics. The dynamic rheological analysis exhibited a more stable elastic-like behavior in doughs supplemented with SF ( $G^{\prime} 4936.2 \pm 12.7$, and $\left.G^{\prime \prime} 2338.4 \pm 9.1\right)$. Organic acid production changes were the most significant, especially for the lactic, citric, and tartaric content.
\end{abstract}

Keywords: dough fermentation; lactic acid bacteria; rheology; soy flour; wheat flour; organic acid

\section{Introduction}

The global food industry confronts serious challenges to provide consistent nutrition [1,2]. Cereals are classified among the primary food resources worldwide [3], wheat (Triticum aestivum L.) represents an essential cereal produced in the world, and it is also highly consumed, especially in Europe [4]. In the bakery industry, doughs are made mainly of refined wheat flour, owing to its particular viscoelastic features resulting mostly from the gluten network (gliadins and glutenins). Although bread produced from wheat flour (WF) has a high energy source, nutritionally, it is unsatisfactory with low mineral and fiber content [5]. Several studies search for alternative ingredients (i.e., amaranth, aleurone, potato, quinoa, etc.) as a substitute, in bakery products to increase its nutritional quality [5-8]. Soybean (Glycine max L.) is part of the Fabaceae family, with particularly high nutrient content like carbohydrates, lipids, proteins, minerals, fibers, vitamins, and has low saturated fat content $[9,10]$. Soybeans are rich in isoflavones (phytoestrogens) like daidzein and genistein, which specifically contribute to the biological activity of soybean that aroused considerable interest in functional food preparation [11]. As demonstrated, fermentation improves the sensory and physicochemical characteristics of soy-based products and has several health benefits [12]. 
An ancient biotechnological process is sourdough fermentation that is highly used in the food industry and was a unique bread leavening technique preceding the breakthrough of yeast fermentation [13]. Generally, sourdough fermentation has a positive effect on WF-based products, as a consequence of low $\mathrm{pH}$ on dough constituent's structure formation like arabinoxylans, starch, and gluten. Lactic acid bacteria (LAB) have a positive influence on bread quality, especially regarding shelf life, texture, nutrition, and flavor resulting in a product free of additives [14]. Through fermentation, carbohydrates are consumed being essential for the growth of $\mathrm{LAB}$, and starch metabolization also leads to a drop in $\mathrm{pH}$ which enhances organic acid production [15]. LAB also have the ability to metabolize through hydrolysis the nondigestible oligosaccharides found in soy, like glycinin G1, $\beta$-conglycinin, and $2 \mathrm{~S}$ albumin giving the final product flavors and aroma [16,17]. Lactobacillus plantarum (LP) is a facultative heterofermentative bacteria that use the Embden-Meyerhof-Parnas (EMP) pathway (Figure 1A) to break down glucose and generate lactic acid [18-20].

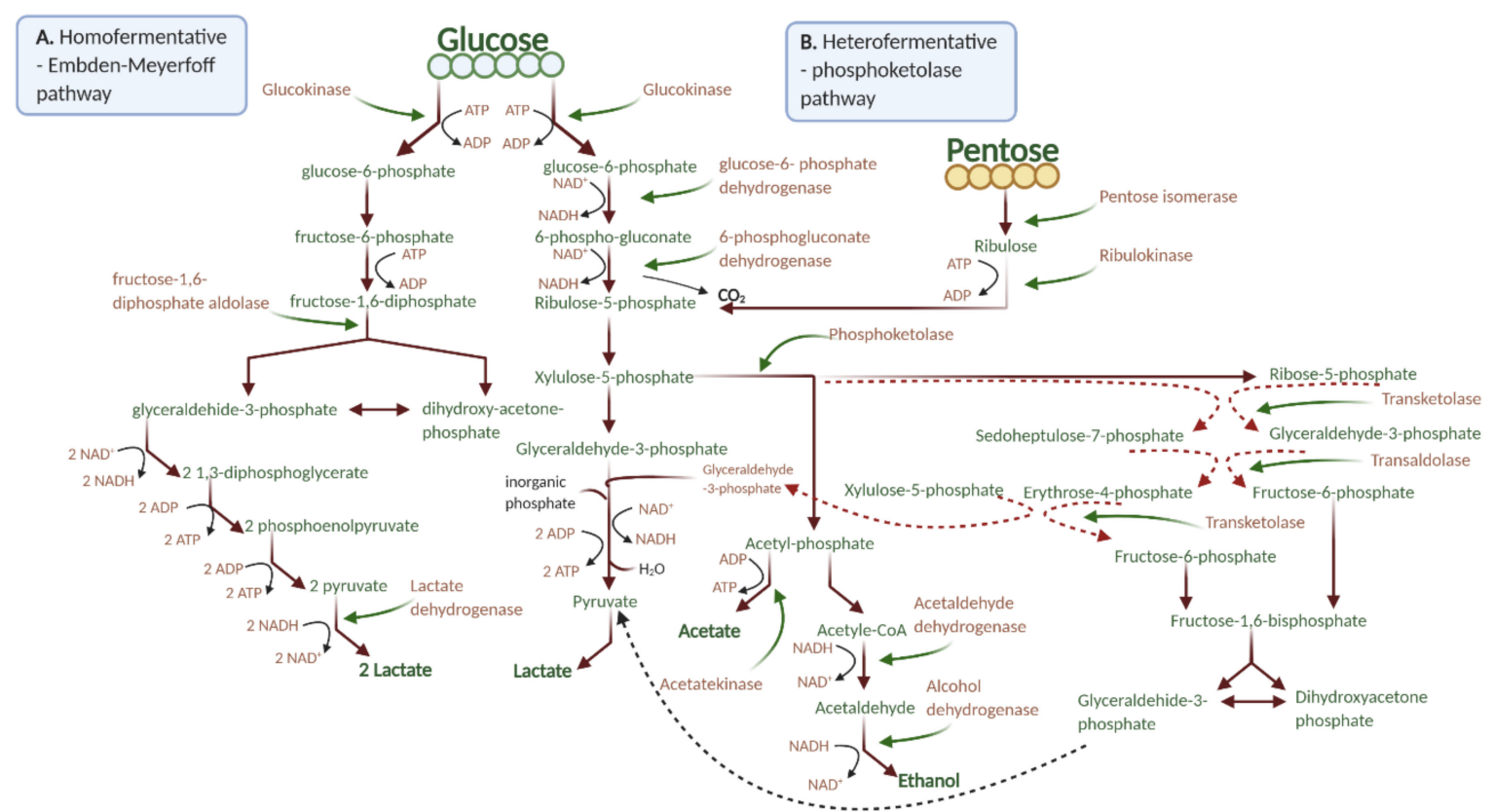

Figure 1. Glucose fermentation pathway. (A) Homofermentative metabolism (through Embden-Meyerhoff pathway); (B) heterofermentative metabolism (phosphoketolase pathway) (image created using BioRender application https://app.biorender.com).

This bacteria adapts easily, has an enhanced sourdough acidification rate, and is pliable with other bacteria or yeasts in cocultures [21]. Lactobacillus casei $(L C)$ has the same adaptability, like $L P$, and can generate lactic acid through EMP (Figure 1A) and phosphoketolase pathways (Figure 1B), which leads to homo- and heterolactic fermentation [21]. LC is widely incorporated in foodstuffs owed to its appealing technological characteristics and health benefits [22,23]. Furthermore, dough fermentation has several beneficial effects, like the pretreatment of the substrate, through increasing and stabilizing the functional quality of the fermented dough. Moreover, it produces a diminished glycemic reaction, positively impacts allergic and intolerance effects in individuals, and increases the absorption of vitamins, minerals, and phytochemicals [24,25].

Through fermentation the rheological property of dough is influenced by many factors, like the content of sodium [26], the type of microorganism found in the fermented dough [16,27], the type of substrate used [14,28], and by the addition of different oleogels [29], proteins [30-32], or alternative sweeteners $[33,34]$. The impact of soy proteins on the wheat dough is highly studied $[35,36]$. The viscoelastic characteristics of wheat dough are given by its gluten network, and the consequence of incorporating different proteins might have a negative impact on bread 
properties [37]. The incorporation of soy-flour (SF) presents foam-stabilizing, moisture-holding potential, gelation, emulsifying activities, and through disulphide-linkages offers elasticity to bread products [32]. Additionally, a recent study proved that the enzyme $\beta$-glucosidase found in LAB can effectively increase the aglycone content of soybean products. An important aspect that should be analyzed through bread making is the property of dough after frozen storage, which can be effectively characterized through rheology [38].

The cocultivation of two LAB ( $L P$ and $L C$ ) on WF-SF substrates has not been studied only together with Saccharomyces cerevisiae (Sc) and especially on model media (MM) [21,39]. Fermentation with only LAB cocultures is important to see their competitiveness and organic acid production capabilities in bakery products. Additionally, the use of LAB as starter cultures in dough fermentation can increase the mineral availability, due to phytate degrading enzymes [40]. Only a few studies analyzed dough fermented exclusively by LAB, which could provide help to people suffering from various health problems [41]. An important aspect that needs to be better analyzed is the change during fermentation with LAB on different substrates and the effect of SF incorporation in WF doughs. Therefore, the present article has the objective to investigate the impact of SF incorporation in WF, through $L A B$ coculture fermentation with $L P$ and $L C$. Besides the dynamic rheological properties of three different concentrations of WF and SF doughs, the chemical properties, cell growth, and $\mathrm{pH}$ were also evaluated.

\section{Materials and Methods}

\subsection{Strains and Culture Conditions}

The fermentations involved two types of LAB, namely Lb. plantarum ATCC $8014(L P)$ and Lb. casei ATCC $393(L C)$ acquired from the University of Agricultural Science and Veterinary Medicine Cluj-Napoca. Culture media constituent elements and every reagent were of analytical grade. For both microorganisms MRS broth (casein peptone-tryptic digest $10 \mathrm{~g} / \mathrm{L}$; meat extract $10 \mathrm{~g} / \mathrm{L}$; yeast extract $5 \mathrm{~g} / \mathrm{L}$; glucose $20 \mathrm{~g} / \mathrm{L}$; Tween $801 \mathrm{~g} / \mathrm{L} ; \mathrm{K}_{2} \mathrm{HPO}_{4} 2 \mathrm{~g} / \mathrm{L} ; \mathrm{Na}$-acetate $5 \mathrm{~g} / \mathrm{L} ;\left(\mathrm{NH}_{4}\right)_{3}$ citrate $2 \mathrm{~g} / \mathrm{L}$; $\mathrm{MgSO}_{4} \times 7 \mathrm{H}_{2} \mathrm{O} 0.2 \mathrm{~g} / \mathrm{L} ; \mathrm{MnSO}_{4} \times \mathrm{H}_{2} \mathrm{O} 2 \mathrm{~g} / \mathrm{L}$; distilled water $1000 \mathrm{~mL}$ ) was used.

\subsection{Dough Preparation}

The soy-flour utilized in this study originated from the Agricultural Research and Development Center Turda. The soybean type was Onix (Glycine max (L.) Merril), with a traditional cultivation method (tillage) using $60 \%$ of green fertilizer (vegetable debris). A commercially available wheat flour (type 000 , in conformity with Romanian ash content categorization) was used, having $11.2 \%$ protein and $15.3 \%$ moisture content. Three types of flour concentrations were prepared for fermentation, composed of $90 \%$ WF enriched with 10\% SF (batch A), 95\% WF enriched with 5\% SF (batch B), and $100 \% \mathrm{WF}$ (batch C). The quantity of water added to the different flour concentrations (100 g of flour) was $60 \%$ of the whole formulations, while $40 \%$ was the inoculum composed of the two LABs used as coculture, with a total dough amount of $200 \mathrm{~g}$. Before inoculation, the different WF-SF concentrations were sterilized, together with the necessary amount of distilled water, after which they were mixed thoroughly and inoculated with the activated and necessary amount of LAB as presented in our previous study Teleky et al. (2020) [39].

\subsection{Model Media and Dough Fermentation}

Model media (MM) cultured the same way as presented in a previous study [39], and the dough was inoculated with the microorganisms $L P$ and $L C$ in a concentration of $10^{8} \mathrm{CFU} / \mathrm{mL}$. The final volume of MM was $500 \mathrm{~mL}$, and each dough combination had a final volume of $200 \mathrm{~mL}$ and was inoculated with the same amount of inoculum from both LAB. Sample extraction occurred at every $4 \mathrm{~h}(0,4,8,12$, $24 \mathrm{~h}$ ) with $5 \mathrm{~mL}$ of sample for high-performance liquid chromatography (HPLC) analysis, $5 \mathrm{~mL}$ for $\mathrm{pH}$, $1 \mathrm{~mL}$ for viability, and $5 \mathrm{~mL}$ for rheological measurements. 


\subsection{Testing Methods}

\subsection{1. $\mathrm{pH}$}

$\mathrm{pH}$ evaluation was established with a digital $\mathrm{pH}$ meter (InoLab 7110, Wellheim, Germany). Samples were dissolved with $45 \mathrm{~mL}$ of distilled water at room temperature and measured while the samples were homogenized continuously with a magnetic stirrer [42].

\subsubsection{Cell Viability}

LAB viability was established by diluting $1 \mathrm{~mL}$ of prelevated sample in $9 \mathrm{~mL}$ of sterile saline solution and processed with the spread plate method and incubated for $24 \mathrm{~h}$ at $37^{\circ} \mathrm{C}$ [43]. The viability of LAB was evaluated through plate counting and colony-forming units $/ \mathrm{mL}$ sample and was displayed in logarithmic values of colony-forming units/milliliter of the sample $(\log 10 \mathrm{CFU} / \mathrm{mL})$.

\subsubsection{Rheological Properties}

Samples for rheological analysis were stored at $-20^{\circ} \mathrm{C}$, defrosted at room temperature after which they were analyzed with an Anton Paar MCR 72 rheometer (Anton Paar, Graz, Austria) [44,45]. The dynamic rheological measurements were performed with a Peltier plate-plate system (P-PTD 200/Air) supplied with temperature control, and with a smooth parallel plate geometry (PP-50-67300) of $50 \mathrm{~mm}$. Shear strain (oscillating) was set at a constant value of $0.1 \%$ and angular frequency $(\omega)$ at a logarithmic ramp and set between the intervals of 0.628-628 rad/s. After the sample supplying, the gap between plates was set at $1 \mathrm{~mm}$, the dough surplus was trimmed, and to prevent the sample from drying, silicone oil was distributed on the exterior.

\subsubsection{HPLC}

Organic acid consumption and production were measured by HPLC (Agilent 1200 series, Santa Clara, CA, USA) after the samples were filtered (for MM) or homogenized (for dough, $1 \mathrm{~g}$ of sample with $2 \mathrm{~mL}$ of distilled water), vortexed, sonicated, centrifuged, and filtered $(0.45 \mu \mathrm{m}$ pore size). The HPLC was provided with a solvent degasser, DAD detector coupled with a mass detector, quaternary pump, thermostat column, and an automatic injector (Agilent Technologies, Santa Clara, CA, USA). In the column, a volume of $20 \mu \mathrm{L}$ of the sample was injected, with a $0.5 \mathrm{~mL} / \mathrm{min}$ sample flow rate, and detection was carried out at 280 and $340 \mathrm{~nm}$. The organic acid separation was accomplished on a reversed-phase chromatographic column Acclaim OA $(5 \mu \mathrm{m}, 4 \times 150 \mathrm{~mm}$ Dionex), washed with $\mathrm{NaH} 2 \mathrm{PO} 450 \mathrm{mM}$ concentration ( $\mathrm{pH}$ 2.8) solution for $10 \mathrm{~min}$, at $20^{\circ} \mathrm{C}$, and with a $0.5 \mathrm{~mL} / \mathrm{min}$ flow rate. Chromatogram measurement was performed at a $\lambda=210 \mathrm{~nm}$ wavelength [46,47]. Organic acid standard stock solution (Merck) was prepared by mixing the components (lactic, tartaric, malic, citric, succinic, fumaric, butyric acids) (Supplementary Figure S1).

\subsubsection{Statistical Analysis}

Every measurement was performed in triplicate and expressed as mean value $( \pm S D, n=3)$. The statistical interpretation was performed with the help of Graph Prism Version 8.0.1. (GraphPad Software Inc., San Diego, CA, USA) with a one-way ANOVA test (Tukey multiple comparisons tests) [48]. Statistically significant differences of means were considered at a $5 \%$ level.

\section{Results and Discussion}

\section{1. $L A B$ Viability and $p H$}

LABs are one of the most frequently used microorganisms in sourdough fermentation, and the use of appropriate starter cultures have great importance. In SF the carbon:nitrogen ratio is not satisfactory for the growth of $\mathrm{LAB}$, and various carbon sources can influence the metabolism and growth of $L P$ and LC [49]. Through fermentation on every WF and SF concentration, the growth of LAB cocultures 
increased from an average value of 6.1-6.4 $\log 10 \mathrm{CFU} / \mathrm{mL}$, which was very similar in every batch, to $10.8-10.9 \log 10 \mathrm{CFU} / \mathrm{mL}$ (Figure 2).

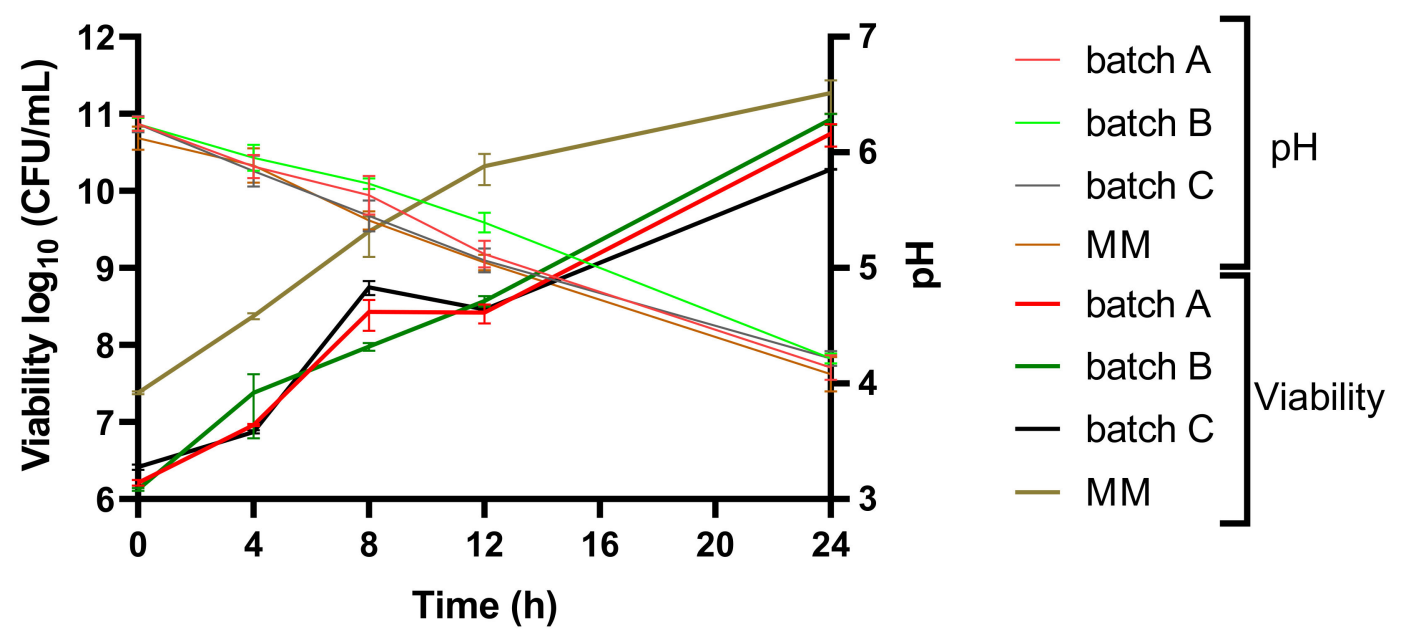

Figure 2. Cell viability (spread plate method) and $\mathrm{pH}$ profile of the fermentations at the three different substrate concentrations (wheat and soy-flour) and MM for $24 \mathrm{~h}$ with the cocultures. Values for LAB viable cell growth and $\mathrm{pH}$ are displayed as mean values $\pm \mathrm{SD}, \log 10 \mathrm{CFU} / \mathrm{mL}, \mathrm{n}=3$, GraphPad Prism Version 8.0.1 (Graph Pad Software, Inc., San Diego, CA, USA); batch A ( $90 \%$ WF $+10 \%$ SF addition); batch B (95\% WF + 5\% SF addition); batch C (100\% WF), MM (model media); CFU/mL (colony-forming units/milliliter of sample).

Through the fermentation, the values gradually increased and reached a final concentration of 10.8-10.9 $\log 10 \mathrm{CFU} / \mathrm{mL}$ on substrates where SF was added and $10.3 \log 10 \mathrm{CFU} / \mathrm{mL}$ where only WF was the sole substrate. In MM, the viability was considerably higher, with final values reaching $11.5 \log 10 \mathrm{CFU} / \mathrm{mL}$. The same trend could be observed at viability with the cocultures of $L P, L C$, and Sc [39], where a final concentration of $10.4 \log 10 \mathrm{CFU} / \mathrm{mL}$ was reached in the case of flour as substrate and $12.5 \log 10 \mathrm{CFU} / \mathrm{mL}$ in the case of MM. Dough enriched with SF had a beneficial effect on viability which can be justified by the ability of LAB to degrade soy as substrate, particularly $L P$ [50].

Throughout fermentation, the $\mathrm{pH}$ gradually decreased, but in the case of $\mathrm{MM}$ and batch $\mathrm{C}$, the $\mathrm{pH}$ decreased more rapidly, owing to better accessibility of carbohydrates. A similar decline in $\mathrm{pH}$ could be observed in a study on different carbohydrates with starting values of about 6.1 and final values between 4.4 and 4.8 [21]. The decrease in $\mathrm{pH}$ is caused by the production of organic acids through fermentation by LAB especially lactic acid. With the continuous metabolic activities of the LAB, the $\mathrm{pH}$ reached lower values than $<4.3$ at the end of fermentation, which can also be seen in several studies led on different substrates [51-53].

\subsection{Viscoelastic Behavior of Dough}

Dough rheology became a field with a great deal of interest in the cereal industry, considering its implication in baked product quality [54]. An essential qualitative parameter of bread products is associated with dough's viscoelasticity, which is given by the gluten complex found in wheat. Through bread-production dough experiences a variety of strains and stresses of different degrees, which are essential in evaluating the viscoelastic behavior of dough. Particularly through fermentation, a significant element is extensional deformation, which has a major impact on the rheological characteristics and consistency of the end-product [32,54].

In Figure 3, and Supplementary Tables S1-S3, the viscoelastic properties of doughs at $30{ }^{\circ} \mathrm{C}$ in all three wheat-soy flour concentrations (batches $\mathrm{A}, \mathrm{B}$, and $\mathrm{C}$ ) through coculture fermentation with $L P$ 
and $L C$ are presented. Every dough combination showed with the increase of angular frequency $(\omega)$ a rise in storage $\left(\mathrm{G}^{\prime}\right)$ and loss modulus $\left(\mathrm{G}^{\prime \prime}\right)$.

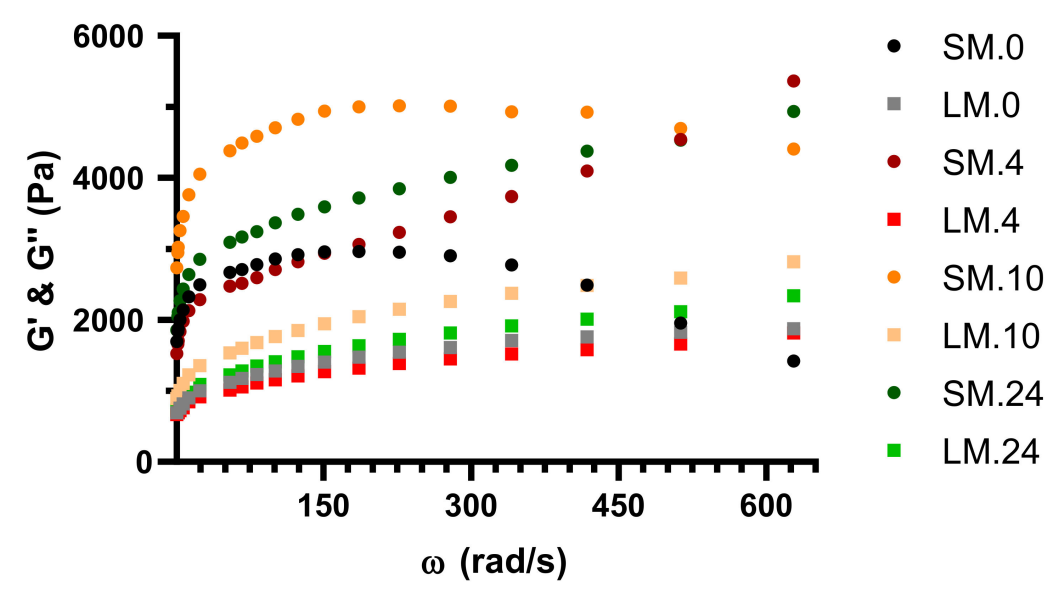

A.

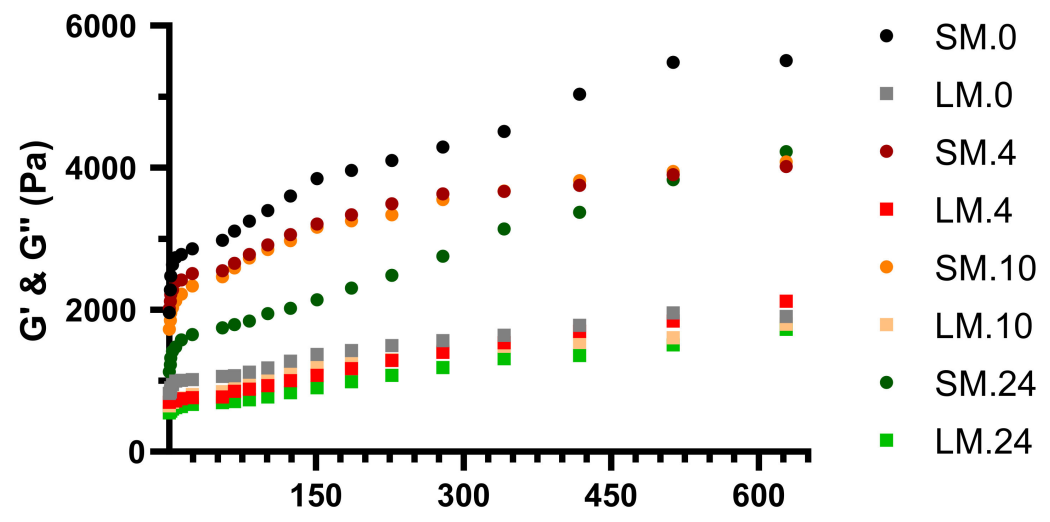

B.

$\omega(\mathrm{rad} / \mathrm{s})$

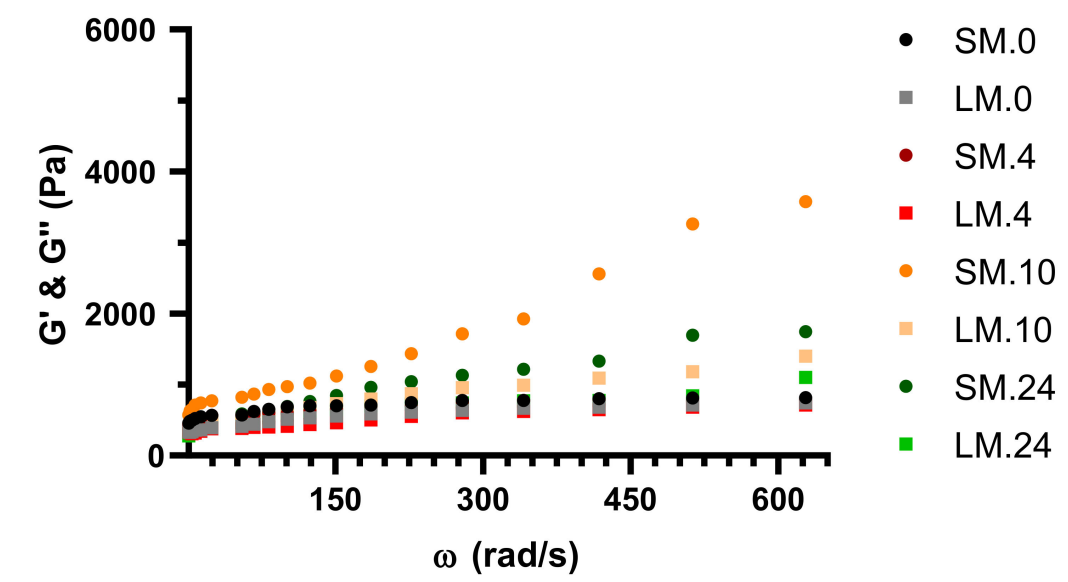

C.

Figure 3. Storage (SM-G', filled dots $\bullet$ ) and loss modulus ( $\mathrm{LM}-\mathrm{G}^{\prime \prime}$, filled squares $\left.\square\right)$ performed as a function of angular frequency $(\omega)$ in doughs at different strengths for (A) batch A $(90 \% \mathrm{WF}+10 \% \mathrm{SF}$ addition); (B) batch B (95\% WF + 5\% SF addition); (C) batch C (100\% WF) fermented with the coculture of $L P$ and $L C$ through a $24 \mathrm{~h}$ period. 
The moisture content of mixtures of WF and SF doughs have different water absorption capacities, which affects the dynamic moduli (with lower water content it amplifies) [55]. As a consequence, the water content of every batch was the same in every experiment. Considering that in every dough sample, the $G^{\prime}$ was higher than the $G^{\prime \prime}$, and also increased with the increase of $\omega$. Consequently, every dough sample presented a weak gel-like behavior (stable elastic behavior). The highest gel-like behavior was observed in the batches where SF was added, with final values at $24 \mathrm{~h}$ fermentation of $\mathrm{G}^{\prime}$ $4936.2 \pm 12.7$, and $G^{\prime \prime} 2338.4 \pm 9.1$ for batch $A$ and $G^{\prime} 4225.2 \pm 11.9$, and $G^{\prime \prime} 1726.7 \pm 10.1$ for batch $B$. The same behavior was reported in several studies where different types of flours were analyzed in dough production, like aleurone, durum, Psyllium, amaranth flour, corn starch, and pea isolate $[5,7,56]$.

Although the addition of SF to WF has a negative impact on bread volume, the sour flavor given by the organic acids hides the odd flavor of soybean, and as a result, the consumer acceptance is favorable [57]. Similar reports stated that soy proteins, besides giving valuable nutritional quality to doughs, also display multiple functional characteristics like emulsifying, gelation action, moisture retention capability, and stabilize the foam activity, which has a good influence on dough products [32,36]. Furthermore, dough fermentation influenced the rheological property of wheat/wheat-soy doughs becoming flexible, easily extensible, with low elasticity [13]. In the batch where no SF was added, $G^{\prime}$, and $G^{\prime \prime}$ had both very low values, although in these samples a small elastic behavior was also observed, with SF addition, this behavior was accentuated.

\subsection{Organic Acid Production}

Sourdough fermentation is an ancient bread-making technique, required for dough leavening. Through fermentation, LAB, which usually exists in flour, produces lactic acid. The production of an appropriate quantity of volatile compounds needs fermentation of approximately $12-24 \mathrm{~h}$, whereas, with baker's yeast, it is sufficient for a couple of hours. For the acidification of dough, usually, the LAB is accountable. Lactic acid and acetic acid play an essential role in the general flavor perception of the produced bakery products. In the production of organic acids, an important role is given to the fermentation temperature, the utilized flour type, and especially the used starter culture (homo- or heterofermentative LAB) [58]. Through EMP, LAB ferment glucose, and carbohydrates are conveyed by the phosphotransferase system transporter systems. Besides glucose, sugars are metabolized under carbon-catabolite regression, fructose is entirely utilized as a carbon source, and pyruvate acts as the main connection point of metabolism [59].

Considering lactic acid production (Figure $4 \mathrm{~A}$ ), at the beginning of fermentation it was either elevated or with no production at all, after which the highest level was observed in batch A with $4661.1 \mathrm{mg} / \mathrm{L}$, followed by batch B with $3440.9 \mathrm{mg} / \mathrm{L}$ and the lowest quantity was $2872.9 \mathrm{mg} / \mathrm{L}$ in batch C. This organic acid was found in a higher amount of $12,306.3 \mathrm{mg} / \mathrm{L}$ in a similar study, on amaranth flour dough fermentation with three LAB strains, LP RTa12, Lb. sakei RTa14, and Pediococcus pentosaceus RTa11 [60]. On different semolina and pistachio powder enriched WF sourdoughs with mixed LAB cocultures, lactic acid was produced between 5210 and $5890 \mathrm{mg} / \mathrm{L}$ without pistachio powder, and $7470-9800 \mathrm{mg} / \mathrm{L}$ in enriched flours, which also resulted in bread with better sensory analysis [53].

Heterofermentative LAB in the fermentation process achieves acidification by organic acid production, especially by lactic and acetic acids, which are also accountable for bread products' shelf-life extension [61]. Even though acetic acid production in the fermented dough was not observed in any of the three batches, in MM from an initial quantity of $3437.7 \mathrm{mg} / \mathrm{L}$ at $0 \mathrm{~h}$, it decreased to $1892.3 \mathrm{mg} / \mathrm{L}$ at $24 \mathrm{~h}$ which is in accordance with similar studies [21,62].

Alongside lactic acid and acetic acid, several organic acids have antimicrobial activities, like citric acid, fumaric acid, malic acid (Figure 4D), tartaric acid (Figure 4F), and butyric acid. Through the decarboxylation of malic acid, lactic acid is produced [63], which in our studies decreased to values of 1366.107 (batch A), 786.589 (batch B), and $824.863 \mathrm{mg} / \mathrm{L}$ (batch C). 

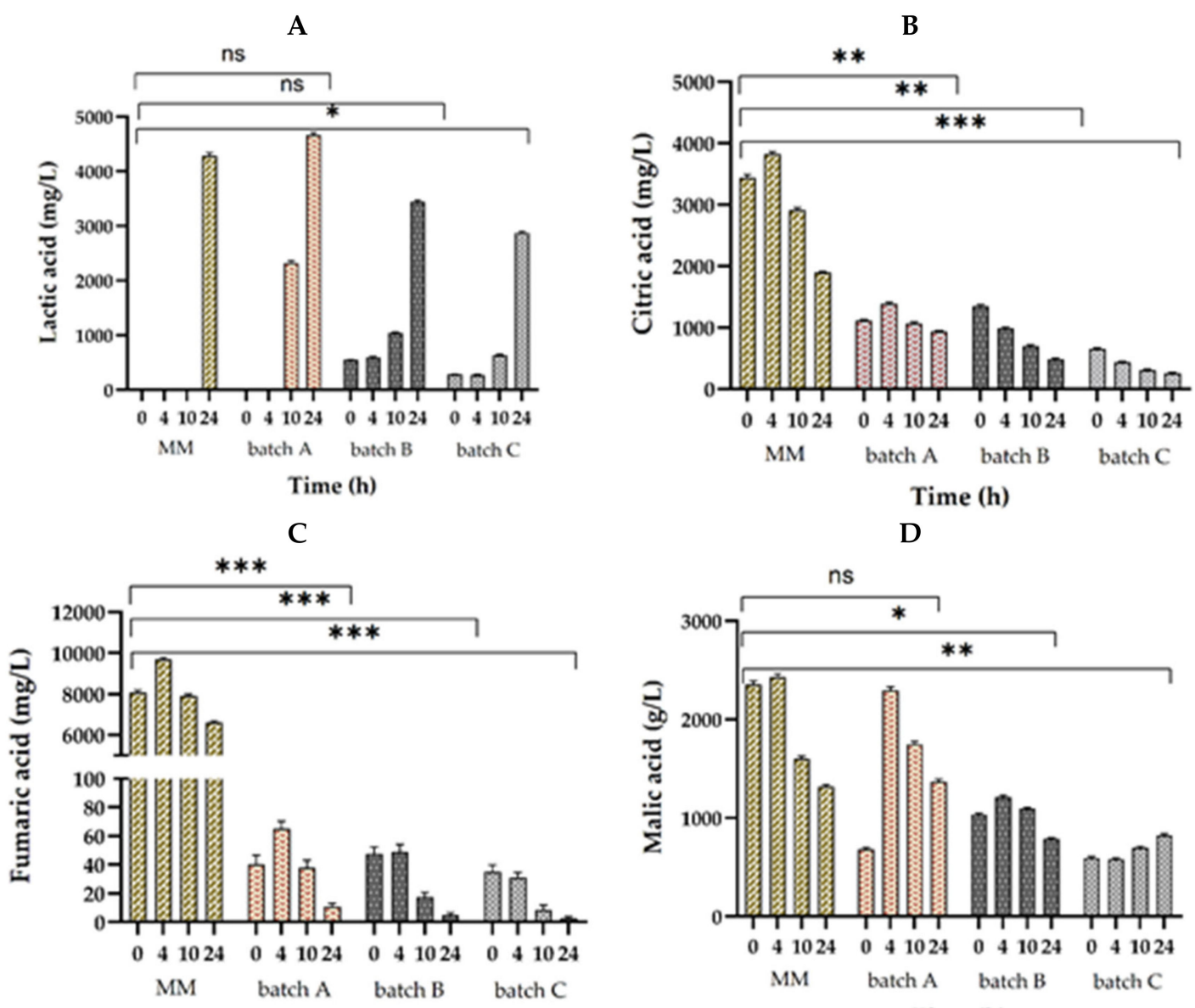

Time (h)

D

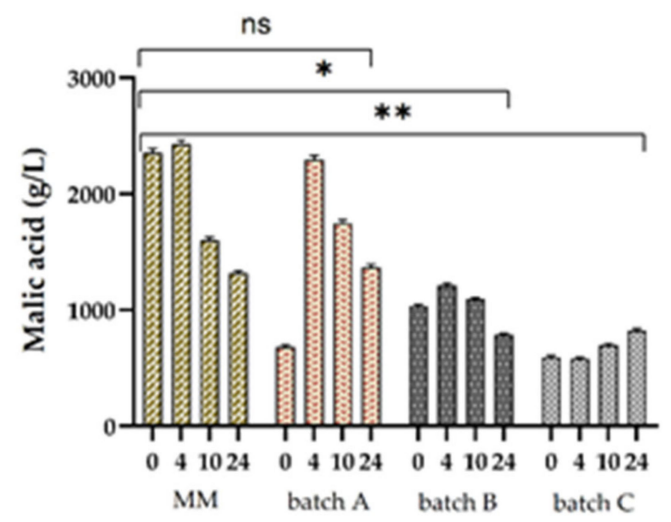

Time (h)

E

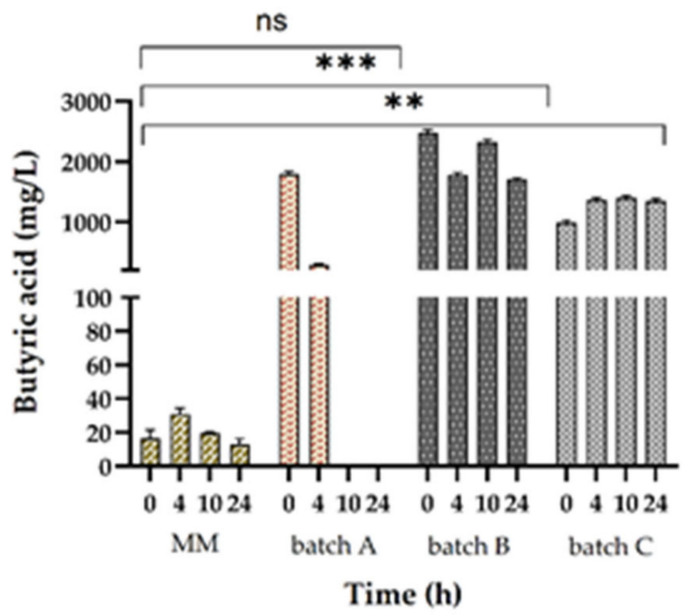

Time (h)

F

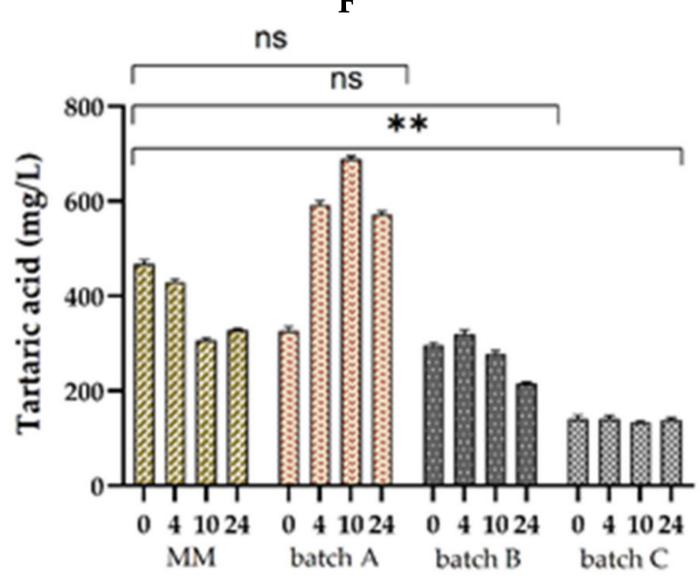

Time (h)

Figure 4. Organic acid production through $24 \mathrm{~h}$ fermentation with the cocultures $L P$ and LC in MM (model media-control); batch A (90\% WF and 10\% SF), B (95\% WF and 5\% SF), and C (100\% WF); (A) lactic acid, (B) citric acid, (C) fumaric acid, (D) malic acid, (E) butyric acid, and (F) tartaric acid. Values displayed as mean \pm SD of the triple measurements and symbols $\left(\mathrm{ns},{ }^{*},{ }^{* *},{ }^{* * *}\right)$ express the not-significant or significant differences $(p<0.05)$ between the MM and the three batches (one-way analysis of variance (ANOVA), multiple comparison tests).

In the three wheat-soy flour doughs, citric acid (Figure 4B) presented inconstant results through fermentation, because generally it is consummated when LAB are low in carbohydrates. Still, at $24 \mathrm{~h}$, the quantity decreased to $931.7,479.6$, and $256.9 \mathrm{mg} / \mathrm{L}$ in the three batches. Simurina et al. (2014) 
stated that the incorporation of citric acid substantially enhances bread quality, and has crumb softening aftermath [64]. Fumaric acid (Figure 4C), although recognized as an advantageous organic acid on human health as a result of its antioxidant activity [65], in these batches it was found in a low quantity. In the three batches from the beginning of the fermentation, it decreased from 35.051-47.510 to $2.673-10.835 \mathrm{mg} / \mathrm{L}$ at $24 \mathrm{~h}$. Su et al. (2019) found that organic acids (lactic, citric, acetic, malic, and fumaric) have a good effect on specific volume, decrease the moisture content, $\mathrm{pH}$, and bread hardness. On the other hand, organic acids also decreased the gas retention capacity and diminished the gluten network [65].

Butyric acid (Figure 4E) is especially beneficial for colon health and has the added capacity to prevent or to treat Crohn's disease, cancer, and distal ulcerative colitis [66]. The production of butyric acid decreased till the end of fermentation, reaching values of $1711.167 \mathrm{mg} / \mathrm{L}$ in batch $\mathrm{B}$ and $1349.320 \mathrm{mg} / \mathrm{L}$ in batch C. In batch A, the butyric acid quantity was not detected after $24 \mathrm{~h}$ of fermentation.

The highest concentration of organic acids (except butyric acid) at the end of fermentation was found in batch $\mathrm{A}$, which indicates that SF addition improves considerably organic acid production. With a final concentration of tartaric acid of $572.508 \mathrm{mg} / \mathrm{L}$, malic acid of $1366.107 \mathrm{mg} / \mathrm{L}$, lactic acid of $4661.098 \mathrm{mg} / \mathrm{L}$, citric acid of $931.690 \mathrm{mg} / \mathrm{L}$, and fumaric acid of $10.835 \mathrm{mg} / \mathrm{L}$, the addition of $10 \%$ of SF has an improved effect on dough quality. In comparison with our earlier results with single fermentation of $L P, L C$, or coculture fermentation of $L P+L C+S c$ [39], the coculture of $L P+L C$ without yeast had the highest organic acid production. $S c$ generates high quantity of $\mathrm{CO}_{2}$ which is accountable for dough leavening. $\mathrm{LAB}$ are also accelerated by $\mathrm{CO}_{2}$, and inhibited by the aerobically produced reactive oxygen species [67]. The lower lactic acid concentration can be explained by the fact that $S c$ consumes this organic acid from dough, but this way [68] increases the growth of LAB by reducing the acidification of the substrate [68].

Cocultivation of $L P$ and $L C$ led to a high concentration of lactic acid, especially where SF was present. As in our earlier study carbohydrate metabolization was better with $L P$ than with $L C$, especially in lactic acid production. In general, in single cultures, organic acid production was higher with $L P$ which indicates that it has a dominant trait in carbohydrate consumption. However, on every substrate combination both LAB showed efficient synergy.

\section{Conclusions}

Dough fermentation with cocultures of $L P+L C$ presented favorable results in organic acid development, especially with an increased lactic $(4661.098 \mathrm{mg} / \mathrm{L})$, citric $(931.690 \mathrm{mg} / \mathrm{L})$, and tartaric $(572.508 \mathrm{mg} / \mathrm{L})$ acid production. The viability of these two LABs, grown at $37{ }^{\circ} \mathrm{C}$, increased to 10.28-11.51 $\log 10 \mathrm{CFU} / \mathrm{mL}$, and the $\mathrm{pH}$ decreased at values between the range of 4.14-4.23. These two LAB had good metabolite production efficiency and both $L b$. strains were in symbiosis with favorable growth dynamics.

In the course of fermentation dough experiences important rheological alterations, which were investigated using dynamic rheological measurements. Besides, the effect of SF incorporation (up to $10 \%$ ) in WF produced several positive changes in the rheological characteristics of dough, like increased elastic-like behavior. Additionally, with the increase of SF, an increase in organic acid content could be observed, which further supports the addition of SF in bakery products.

Further research should be run to evaluate the positive effects of other microorganisms like (i.e., Lb. florum, Lb. bulgaricus, Oenococcus oeni, etc.) through dough fermentation in single or cocultures, together or without the addition of baker's yeast (S. cerevisiae), and also the effect of higher substitution of SF to WF. As a future scope, the consequence of SF addition to WF through frozen storage in comparison with the unfrozen dough will be performed. The interferences of LAB in cocultures and their metabolic activity with the effect on dough characteristics is important. 
Supplementary Materials: The following are available online at http://www.mdpi.com/2304-8158/9/12/1894/s1, Figure S1. HPLC chromatogram of organic acid standards and retention times; Table S1. Cell viability and $\mathrm{pH}$ profile of the fermentations at the three different substrate concentrations (wheat and soy-flour) and $\mathrm{MM}$ for $24 \mathrm{~h}$ with the cocultures; Table S2. The standard deviation of storage $\left(G^{\prime}\right)$ and loss $\left(G^{\prime \prime}\right)$ shear moduli for $100 \%$ wheat flour with $L P+L C$ cocultures; Table S3. The standard deviation of storage $\left(\mathrm{G}^{\prime}\right)$ and loss $\left(\mathrm{G}^{\prime \prime}\right)$ shear moduli for $95 \%$ wheat flour and $5 \%$ soy flour with $L P+L C$ cocultures; Table 54 . The standard deviation of storage $\left(\mathrm{G}^{\prime}\right)$ and loss $\left(G^{\prime \prime}\right)$ shear moduli for $90 \%$ wheat flour and $10 \%$ soy flour with $L P+L C$ cocultures.

Author Contributions: D.C.V. and B.-E.T. conceived and designed the study. B.-E.T., G.A.M. performed the experiments. D.C.V., B.-E.T., and G.A.M. undertook the data analysis and cowrote the paper. All authors have read and agreed to the published version of the manuscript.

Funding: This work was supported by the National Research, Development and Innovations Programme for 2015-2020-PNII, developed with the support of UEFISCDI (Project No. PN-III-P1-1.2-PCCDI-2017-0056; 2PCCDI).

Acknowledgments: The authors would like to thank their colleagues from the Department of Food Science, for continued support.

Conflicts of Interest: The authors declare no conflict of interest. The funders had no role in the design of the study; in the collection, analyses, or interpretation of data; in the writing of the manuscript, or in the decision to publish the results.

\section{References}

1. Saget, S.; Costa, M.; Barilli, E.; Wilton, M.; Vasconcelos, D.; Sancho, C.; Styles, D.; Williams, M. Substituting wheat with chickpea flour in pasta production delivers more nutrition at a lower environmental cost. Sustain. Prod. Consum. 2020, 24, 26-38. [CrossRef]

2. Chis, M.S.; Paucean, A.; Man, S.M.; Bonta, V.; Pop, A.; Stan, L.; Beldean, B.V.; Pop, C.R.; Mureșan, V.; Muste, S.; et al. Effect of rice flour fermentation with Lactobacillus spicheri DSM 15429 on the nutritional features of gluten-free muffins. Foods 2020, 9, 822. [CrossRef]

3. Călinoiu, L.F.; Vodnar, D.C. Whole grains and phenolic acids: A review on bioactivity, functionality, health benefits and bioavailability. Nutrients 2018, 10, 1615. [CrossRef] [PubMed]

4. Wang, J.; Chatzidimitriou, E.; Wood, L.; Hasanalieva, G.; Markelou, E.; Iversen, P.O.; Seal, C.; Baranski, M.; Vigar, V.; Ernst, L.; et al. Effect of wheat species (Triticum aestivum vs. T. spelta), farming system (organic vs. conventional) and flour type (wholegrain vs. white) on composition of wheat flour-Results of a retail survey in the UK and Germany-2. Antioxidant activity, and phenoli. Food Chem. X 2020, 6, 100091. [CrossRef] [PubMed]

5. Guardianelli, L.M.; Salinas, M.V.; Puppo, M.C. Hydration and rheological properties of amaranth-wheat flour dough: Influence of germination of amaranth seeds. Food Hydrocoll. 2019, 97, 105242. [CrossRef]

6. Yamul, D.K.; Navarro, A.S. Effect of hydrocolloids on structural and functional properties of wheat/potato (50/50) flour dough. Food Struct. 2020, 24, 100138. [CrossRef]

7. Xu, M.; Hou, G.G.; Ma, F.; Ding, J.; Deng, L.; Kahraman, O.; Niu, M.; Trivettea, K.; Lee, B.; Wu, L.; et al. Evaluation of aleurone flour on dough, textural, and nutritional properties of instant fried noodles. LWT 2020, 126, 109294. [CrossRef]

8. Paucean, A.; Man, S.M.; Chis, M.S.; Mureşan, V.; Pop, C.R.; Socaci, S.A.; Muresan, C.C.; Muste, S. Use of pseudocereals preferment made with aromatic yeast strains for enhancing wheat bread quality. Foods 2019, 8, 443. [CrossRef]

9. Jayachandran, M.; Xu, B. An insight into the health benefits of fermented soy products. Food Chem. 2019, 271, 362-371. [CrossRef]

10. Hu, C.; Wong, W.-T.; Wu, R.; Lai, W.-F. Biochemistry and use of soybean isoflavones in functional food development. Crit. Rev. Food Sci. Nutr. 2019, 1-15. [CrossRef]

11. Simmons, A.L.; Smith, K.B.; Vodovotz, Y. Soy ingredients stabilize bread dough during frozen storage. J. Cereal Sci. 2015, 56, 232-238. [CrossRef]

12. Bojňanská, T.; Šmitalová, J.; Vollmannová, A.; Tokár, M.; Vietoris, V. Bakery products with the addition of soybean flour and their quality after freezer storage of dough. J. Microbiol. Biotechnol. Food Sci. 2015, 4, 18-22. [CrossRef]

13. Angioloni, A.; Romani, S.; Pinnavaia, G.G.; Rosa, M.D. Characteristics of bread making doughs: Influence of sourdough fermentation on the fundamental rheological properties. Eur. Food Res. Technol. 2006, 222, 54-57. [CrossRef] 
14. Zhang, Y.; Hong, T.; Yu, W.; Yang, N.; Jin, Z.; Xu, X. Structural, thermal and rheological properties of gluten dough: Comparative changes by dextran, weak acidification and their combination. Food Chem. 2020, 330, 127154. [CrossRef] [PubMed]

15. Chiş, M.S.; Păucean, A.; Man, S.M.; Vodnar, D.C.; Teleky, B.E.; Pop, C.R.; Stan, L.; Borsai, O.; Kadar, C.B.; Urcan, A.C.; et al. Quinoa sourdough fermented with Lactobacillus plantarum ATCC 8014 designed for gluten-free muffins-A powerful tool to enhance bioactive compounds. Appl. Sci. 2020, 10, 7140. [CrossRef]

16. Masiá, C.; Jensen, P.E.; Buldo, P. Effect of Lactobacillus rhamnosus on physicochemical properties of fermented plant-based raw materials. Foods 2020, 9, 1182. [CrossRef] [PubMed]

17. Shirotani, N.; Bygvraa, A.; Lametsch, R.; Agerlin, M.; Rattray, F.P.; Ipsen, R. Proteolytic activity of selected commercial Lactobacillus helveticus strains on soy protein isolates. Food Chem. 2020, 340, 128152. [CrossRef]

18. Brizuela, N.; Tymczyszyn, E.E.; Semorile, L.C.; Valdes La Hens, D.; Delfederico, L.; Hollmann, A.; Bravo-Ferrada, B. Lactobacillus plantarum as a malolactic starter culture in winemaking: A new (old) player? Electron. J. Biotechnol. 2019, 38, 10-18. [CrossRef]

19. Collado-Fernández, M. Bread and dough fermentation. Encycl. Food Sci. Nutr. 2003, 1997, 647-655. [CrossRef]

20. Endo, A.; Dicks, L.M.T. Physiology of the LAB. In Lactic Acid Bacteria: Biodiversity and Taxonomy; Wiley Blackwell: Hoboken, NJ, USA, 2014; pp. 13-30.

21. Paucean, A.; Vodnar, D.C.; Socaci, S.A.; Socaciu, C. Carbohydrate metabolic conversions to lactic acid and volatile derivatives, as influenced by Lactobacillus plantarum ATCC 8014 and Lactobacillus casei ATCC 393 efficiency during in vitro and sourdough fermentation. Eur. Food Res. Technol. 2013, 237, 679-689. [CrossRef]

22. Saxami, G.; Ypsilantis, P.; Sidira, M.; Simopoulos, C.; Kourkoutas, Y.; Galanis, A. Distinct adhesion of probiotic strain Lactobacillus casei ATCC 393 to rat intestinal mucosa. Anaerobe 2012, 18, 417-420. [CrossRef] [PubMed]

23. Pop, O.L.; Dulf, F.V.; Cuibus, L.; Castro-Giráldez, M.; Fito, P.J.; Vodnar, D.C.; Coman, C.; Socaciu, C.; Suharoschi, R. Characterization of a sea buckthorn extract and its effect on free and encapsulated Lactobacillus casei. Int. J. Mol. Sci. 2017, 18, 2513. [CrossRef] [PubMed]

24. Gobbetti, M.; Rizzello, C.G.; Di Cagno, R.; De Angelis, M. How the sourdough may affect the functional features of leavened baked goods. Food Microbiol. 2014, 37, 30-40. [CrossRef] [PubMed]

25. Martău, G.A.; Coman, V.; Vodnar, D.C. Recent advances in the biotechnological production of erythritol and mannitol. Crit. Rev. Biotechnol. 2020, 40, 608-622. [CrossRef]

26. Voinea, A.; Stroe, S.-G.; Codină, G.G. The effect of sodium reduction by sea salt and dry sourdough addition on the wheat flour dough rheological properties. Foods 2020, 9, 610. [CrossRef] [PubMed]

27. Yildirim-Mavis, C.; Yilmaz, M.T.; Dertli, E.; Arici, M.; Ozmen, D. Non-linear rheological (LAOS) behavior of sourdough-based dough. Food Hydrocoll. 2019, 96, 481-492. [CrossRef]

28. Autio, K.; Flander, L.; Kinnunen, A.; Heinonen, R. Bread quality relationship with rheological measurements of wheat flour dough. Cereal Chem. 2001, 78, 654-657. [CrossRef]

29. Oh, I.; Lee, S. Rheological, microstructural, and tomographical studies on the rehydration improvement of hot air-dried noodles with oleogel. J. Food Eng. 2020, 268. [CrossRef]

30. Marco, C.; Rosell, C.M. Functional and rheological properties of protein enriched gluten free composite flours. J. Food Eng. 2008, 88, 94-103. [CrossRef]

31. Sozer, N. Rheological properties of rice pasta dough supplemented with proteins and gums. Food Hydrocoll. 2009, 23, 849-855. [CrossRef]

32. Zhou, J.; Liu, J.; Tang, X. Effects of whey and soy protein addition on bread rheological property of wheat flour. J. Texture Stud. 2018, 49, 38-46. [CrossRef] [PubMed]

33. Psimouli, V.; Oreopoulou, V. The effect of alternative sweeteners on batter rheology and cake properties. J. Sci. Food Agric. 2012, 92, 99-105. [CrossRef] [PubMed]

34. Asghar, A.; Anjum, F.M.; Butt, M.S.; Randhawa, M.A.; Akhtar, S. Effect of polyols on the rheological and sensory parameters of frozen dough pizza. Food Sci. Technol. Res. 2012, 18, 781-787. [CrossRef]

35. Omedi, J.O.; Huang, W.; Su, X.; Liu, R.; Tang, X.; Xu, Y.; Rayas-Duarte, P. Effect of five lactic acid bacteria starter type on angiotensin-I converting enzyme inhibitory activity and emulsifying properties of soy flour sourdoughs with and without wheat bran supplementation. J. Cereal Sci. 2016, 69, 57-63. [CrossRef]

36. Ammar, A.S.; Salem, S.A.; Badr, F.H. Rheological properties of wheat flour dough as affected by addition of whey and soy proteins. Pakistan J. Nutr. 2011, 10, 302-306. [CrossRef]

37. Crockett, R.; Ie, P.; Vodovotz, Y. Effects of soy protein isolate and egg white solids on the physicochemical properties of gluten-free bread. Food Chem. 2015, 129, 84-91. [CrossRef] 
38. Yang, S.; Jeong, S.; Lee, S. Elucidation of rheological properties and baking performance of frozen doughs under different thawing conditions. J. Food Eng. 2020, 284, 110084. [CrossRef]

39. Teleky, B.E.; Martău, A.G.; Ranga, F.; Chețan, F.; Vodnar, D.C.; Gheorghe, A.; Chet, F. Exploitation of lactic acid bacteria and baker's yeast as single or multiple starter cultures of wheat flour dough enriched with soy flour. Biomolecules 2020, 10, 778. [CrossRef] [PubMed]

40. De Angelis, M.; Rizzello, C.G.; Alfonsi, G.; Arnault, P.; Cappelle, S.; Cagno, R.D.; Gobbetti, M. Use of sourdough lactobacilli and oat fibre to decrease the glycaemic index of white wheat bread. Br. J. Nutr. 2007, 98, 1196-1205. [CrossRef]

41. Bottani, M.; Brasca, M.; Ferraretto, A.; Cardone, G.; Casiraghi, M.C.; Lombardi, G.; De Noni, I.; Cattaneo, S.; Silvetti, T. Chemical and nutritional properties of white bread leavened by lactic acid bacteria. J. Funct. Foods 2018, 45, 330-338. [CrossRef]

42. Mitrea, L.; Trif, M.; Vodnar, D.-C. The effect of crude glycerol impurities on 1,3-propanediol biosynthesis by Klebsiella pneumoniae DSMZ 2026. Renew. Energy 2020, 153, 1418-1427. [CrossRef]

43. Călinoiu, L.-F.; Catoi, A.-F.; Vodnar, D.C. Solid-state yeast fermented wheat and oat bran as a route for delivery of antioxidants. Antioxidants 2019, 8, 372. [CrossRef] [PubMed]

44. Szabo, K.; Teleky, B.E.; Mitrea, L.; Călinoiu, L.F.; Martău, G.A.; Simon, E.; Varvara, R.A.; Vodnar, D.C. Active packaging-poly (vinyl alcohol) films enriched with tomato by-products extract. Coatings 2020, 10, 141. [CrossRef]

45. Mitrea, L.; Călinoiu, L.-F.F.; Martău, G.-A.; Szabo, K.; Teleky, B.-E.E.; Mureșan, V.; Rusu, A.-V.V.; Socol, C.-T.T.; Vodnar, D.-C.C.; Mărtau, G.A.; et al. Poly (vinyl alcohol)-based biofilms plasticized with polyols and colored with pigments extracted from tomato by-products. Polymers 2020, 12, 532. [CrossRef]

46. Mitrea, L.; Vodnar, D.C. Klebsiella pneumoniae-A useful pathogenic strain for biotechnological purposes: Diols biosynthesis under controlled and uncontrolled pH levels. Pathogens 2019, 8, 293. [CrossRef]

47. Mitrea, L.; Leopold, L.F.; Bouari, C.; Vodnar, D.C. Separation and Purification of Biogenic 1,3-Propanediol from Fermented Glycerol through Flocculation and Strong Acidic Ion-Exchange Resin. Biomolecules 2020, 10, 1601. [CrossRef]

48. Szabo, K.; Diaconeasa, Z.; Catoi, A.; Vodnar, D.C. Screening of Ten Tomato Varieties Processing Waste for Bioactive Components and Their Related Antioxidant and Antimicrobial Activities. Antioxidants 2019, 8, 292. [CrossRef]

49. Zhang, B.; Yang, Z.; Huang, W.; Omedi, J.O.; Wang, F.; Zou, Q.; Zheng, J. Isoflavone aglycones enrichment in soybean sourdough bread fermented by lactic acid bacteria strains isolated from traditional Qu starters: Effects on in-vitro gastrointestinal digestion, nutritional, and baking properties. Cereal Chem. 2018, 96, 129-141. [CrossRef]

50. Aguirre, L.; Hebert, E.M.; Garro, M.S.; Savoy de Giori, G. Proteolytic activity of Lactobacillus strains on soybean proteins. LWT Food Sci. Technol. 2014, 59, 780-785. [CrossRef]

51. Hashemi, S.M.B.; Gholamhosseinpour, A.; Mousavi Khaneghah, A. Fermentation of acorn dough by lactobacilli strains: Phytic acid degradation and antioxidant activity. LWT 2019, 100, 144-149. [CrossRef]

52. Gerez, C.L.; Dallagnol, A.; Rollán, G.; Font de Valdez, G. A combination of two lactic acid bacteria improves the hydrolysis of gliadin during wheat dough fermentation. Food Microbiol. 2012, 32, 427-430. [CrossRef] [PubMed]

53. Gaglio, R.; Alfonzo, A.; Barbera, M.; Franciosi, E.; Francesca, N.; Moschetti, G.; Settanni, L. Persistence of a mixed lactic acid bacterial starter culture during lysine fortification of sourdough breads by addition of pistachio powder. Food Microbiol. 2020, 86, 103349. [CrossRef] [PubMed]

54. Lee, S.; Campanella, O. Impulse viscoelastic characterization of wheat flour dough during fermentation. J. Food Eng. 2013, 118, 266-270. [CrossRef]

55. Edwards, N.M.; Peressini, D.; Dexter, J.E.; Mulvaney, S.J. Viscoelastic properties of durum wheat and common wheat dough of different strengths. Rheol. Acta 2001, 40, 142-153. [CrossRef]

56. Mariotti, M.; Lucisano, M.; Ambrogina Pagani, M.; Perry, K.W.N. The role of corn starch, amaranth flour, pea isolate, and psyllium flour on the rheological properties and the ultrastructure of gluten-free doughs. Food Res. Int. 2009, 42, 963-975. [CrossRef]

57. Gobbetti, M.; De Angelis, M.; Di Cagno, R.; Calasso, M.; Archetti, G.; Rizzello, C.G. Novel insights on the functional/nutritional features of the sourdough fermentation. Int. J. Food Microbiol. 2019, 302, 103-113. [CrossRef] 
58. Hansen, A.; Schieberle, P. Generation of aroma compounds during sourdough fermentation: Applied and fundamental aspects. Trends Food Sci. Technol. 2005, 16, 85-94. [CrossRef]

59. Gänzle, M.G. Lactic metabolism revisited: Metabolism of lactic acid bacteria in food fermentations and food spoilage. Curr. Opin. Food Sci. 2015, 2, 106-117. [CrossRef]

60. Sterr, Y.; Weiss, A.; Schmidt, H. Evaluation of lactic acid bacteria for sourdough fermentation of amaranth. Int. J. Food Microbiol. 2009, 136, 75-82. [CrossRef]

61. Debonne, E.; Van Schoors, F.; Maene, P.; Van Bockstaele, F.; Vermeir, P.; Verwaeren, J.; Eeckhout, M.; Devlieghere, F. Comparison of the antifungal effect of undissociated lactic and acetic acid in sourdough bread and in chemically acidified wheat bread. Int. J. Food Microbiol. 2020, 321, 1-19. [CrossRef]

62. Robert, H.; Gabriel, V.; Lefebvre, D.; Rabier, P.; Vayssier, Y.; Fontagné-Faucher, C. Study of the behaviour of Lactobacillus plantarum and Leuconostoc starters during a complete wheat sourdough breadmaking process. LWT Food Sci. Technol. 2006, 39, 256-265. [CrossRef]

63. Kunkee, R.E. Some roles of malic acid in the malolactic fermentation in wine making. FEMS Microbiol. Rev. 1991, 88, 55-72.

64. Filipcev, B.; Simurina, O.; Bodroza-Solarov, M. Combined effect of xylanase, ascorbic and citric acid in regulating the quality of bread made from organically grown spelt cultivars. J. Food Qual. 2014, 1-11. [CrossRef]

65. Su, X.; Wu, F.; Zhang, Y.; Yang, N.; Chen, F.; Jin, Z.; Xu, X. Effect of organic acids on bread quality improvement. Food Chem. 2019, 278, 267-275. [CrossRef]

66. Huda-Faujan, N.; Abdulamir, A.S.; Fatimah, A.B.; Muhammad Anas, O.; Shuhaimi, M.; Yazid, A.M.; Loong, Y.Y. The impact of the level of the intestinal short chain fatty acids in inflammatory bowel disease patients versus healthy subjects. Open Biochem. J. 2010, 4, 53-58. [CrossRef]

67. Stevens, M.J.A.; Wiersma, A.; de Vos, W.M.; Kuipers, O.P.; Smid, E.J. Improvement of Lactobacillus plantarum Aerobic Growth as Directed by Comprehensive Transcriptome Analysis. Appl. Environ. Microbiol. 2008, 74, 4776-4778. [CrossRef]

68. Sieuwerts, S.; Bron, P.A.; Smid, E.J. Mutually stimulating interactions between lactic acid bacteria and Saccharomyces cerevisiae in sourdough fermentation. LWT Food Sci. Technol. 2018, 90, 201-206. [CrossRef]

Publisher's Note: MDPI stays neutral with regard to jurisdictional claims in published maps and institutional affiliations.

(C) 2020 by the authors. Licensee MDPI, Basel, Switzerland. This article is an open access article distributed under the terms and conditions of the Creative Commons Attribution (CC BY) license (http://creativecommons.org/licenses/by/4.0/). 